\title{
REFORMULATING THE RIOT GRRRL MOVEMENT: SPACE AND SISTERHOOD IN KATHLEEN HANNA'S LYRICS
}

\author{
Soraya Alonso Alconada \\ Universidad del País Vasco (UPV/EHU) \\ salonso033@ikasle.ehu.eus
}

\begin{abstract}
Music has become a crucial domain to discuss issues such as gender, identities and equality. With this study I aim at carrying out a feminist critical discourse analysis of the lyrics by American singer and songwriter Kathleen Hanna (1968-), a pioneer within the underground punk culture and head figure of the Riot Grrrl movement. Covering relevant issues related to women's conditions, Hanna's lyrics put gender issues at the forefront and become a significant means to claim feminism in the underground. In this study I pay attention to the instances in which Hanna's lyrics in Bikini Kill and Le Tigre exhibit a reading of sisterhood and space and by doing so, I will discuss women's invisibility in underground music and broaden the social and cultural understanding of this music.
\end{abstract}

KeYwords: Riot Grrrl, lyrics, space, sisterhood, Kathleen Hanna.

\author{
REFORMULANDO EL MOVIMIENTO RIOT GRRRL: \\ ESPACIO Y SORORIDAD EN LAS LETRAS DE KATHLEEN HANNA
}

\section{RESUMEN}

La música se ha convertido en un espacio en el que debatir temas como el género, la identidad o la igualdad. Con este trabajo pretendo llevar a cabo un análisis crítico del discurso con perspectiva feminista de las letras de canciones de Kathleen Hanna (1968-), cantante y compositora americana, pionera del movimiento punk y figura principal del movimiento Riot Grrrl. Cubriendo temas relevantes relacionados con la condición de las mujeres, las letras de Hanna sitúan temas relacionados con el género en primera línea y se convierten en un medio significativo para reclamar el feminismo en la música underground. Para mi estudio prestaré atención a las ocasiones en las que las letras de Hanna en Bikini Kill y Le Tigre muestran una interpretación del espacio y la sororidad y, con ello, analizaré la invisibilidad de las mujeres en la música underground y ampliaré el entendimiento social y cultural de la misma.

Palabras clave: Riot Grrrl, letras, espacio, sororidad, Kathleen Hanna.

DOI: https://doi.org/10.25145/j.clepsydra.2021.20.05

Revista Clepsydra, 20; febrero 2021, pp. 99-119; ISSN: e-2530-8424 


\section{INTRODUCTION}

This study is framed within the feminist critical discourse analysis since my principal goal is to focus on the lyrics by the American singer and songwriter Kathleen Hanna (participant in the 1990's Riot Grrrl movement and singer in Bikini Kill and Le Tigre) and their influence on feminism. Riot Grrrl bands such as Bikini Kill, Bratmobile, Heavents to Betsy or Huggy Bear broadcast motifs and themes that explore and at the same time illustrate feminist concerns in the 1990s and afterwards. As a case in point, the rave and appeal for a community between girls and the vindication of location in punk venues and other spatial contexts were fundamental representations of the emotional, cultural, political and social enunciations that Hanna's songs were trying to convey. Thus, the main goal of my study is to carry out a critical discourse analysis from a feminist perspective of the instances in which Hanna's lyrics exhibit a reading of these feminist topics. With this, I want to present alternative ways to rethink and re-appropriate discourse in favor of equality. Also I believe that this study proves appropriate to vindicate the usefulness of lyrics' analysis as a potential literary sample that reflects social and cultural themes that are worthy of scholarly examination.

Leading figure Teun A. van Dijk defines critical discourse analysis as a "discourse analytical research that primarily studies the way social-power abuse and inequality are enacted, reproduced, legitimated, and resisted by text and talk in the social and political context" (Van Dijk 466), and derived from it, feminist critical discourse analysis (hereafter FCDA) focuses on those discourses produced by and in society that maintain a patriarchal social order where women are disempowered. First and foremost, this method

contributes to (critical) language and discourse studies a perspective informed by feminist studies, and on the other hand, it suggests the usefulness of language and discourse studies for the investigation of feminist issues in gender and women's studies. (Lazar 142)

Works in this field are proliferating (Lazar 2007; Kendall and Tannen 2001; Litosseliti and Sunderland 2002; Holmes and Meyerhoff 2003) and with my study I argue that analyzing lyrics may match the purpose of FCDA. But before examining the lyrics in detail, it is necessary to place this work in a broader scenario. Thus, I consider it is important to embark on an academic journey from the more general to the particular, to face the complexities of a perspective that targets different topics and concerns within the fields of feminism and music studies. For this reason, I will present first the works of some authors and critics such as Jacques Attali, Susan McClary or Lucy O'Brien in an attempt to confirm the valuable application of FCDA in popular music.

Writing songs implies a strong level of self-involvement. Songs do not only provide meaning, they also convey emotions. Music is a way to express and interact and it can be (un)intentionally used as a tool for understanding and vindication. Indeed, in his book Noise: The Political Economy of Music, French economist and 
writer Jacques Attali affirms that our world today is rather audible than legible, as it was thought to be centuries before: "For twenty-five centuries, Western knowledge has tried to look upon the world. It has failed to understand that the world is not for the beholding. It is for hearing. It is not legible, but audible" (3). Attali suggests that we should try to judge a society by listening to its sounds, by its art, and by its festivals, rather than by its economic or social statistics. According to him, by listening to noise we can better understand where the folly of men and their calculations are leading us, and what hopes are still at hand to be achieved (3). Hence, music turns out to be more than an object of study, and it becomes a way of perceiving the world and a "tool of understanding" (Attali 4). Moreover, music emerges not only as a personal or sociological tool, but also as a non-objectified reflection of political power: "Listening to music is listening to all noise, realizing that its appropriation and control is a reflection of power, that it is essentially political" (Attali 6). The composition, production, distribution and consumption of music ascertain the latent structures of power that sustain the system. In that sense, music becomes a political tool as well. For instance, if men control the production of a record, we can assume that potential women's perspectives will be diminished or belittled; if only middle-class white people participate in the distribution of that same record, it is quite probable that working-class black people will not be targeted as main consumers, hence, that record will probably fail to address them. In this regard, music can also be a social construct that reflects political, social and cultural powers.

As British journalist and writer Lucy O’ Brien states, music becomes a practical channel in order to reveal political discourses:

Political dissent has always been a rich strand within pop music. From the angry blues singers of the 1940s to Communist folkies in the 1950s and the various vast stadium Aid spectacles of the 1980s, performers have used the medium of rock as a mass vehicle for protest. (306)

Music, for instance, has always played an important role in political demonstrations. Protest songs have accompanied activist movements since the beginnings of social action, representing the view of people and achieving the status of anthems (e.g. John Lennon's anti Vietnam war "Give Peace a Chance (1969) and Nina Simone's "Blacklash Blues" (1967) in the civil rights movement). Activism, in general, has always relied on music to voice its many vindications. As Attali explains, music becomes a way of comprehending the politics of the world when it takes a mirroring role "in which every activity is reflected, defined, recorded, and distorted" (5). Moreover, as musicologist Susan McClary suggests, music does not just reflect society ${ }^{1}$ in a passive way:

${ }^{1}$ Different authors have worked on the connection between music and society. Joseph Kotarba and Phillip Vannini, for instance, explain in Understanding Society Through Popular Music that "popular music is one of the most important sources of culture in our society" (xii-xiii); and Charles Hiroshi Garrett, whose focus is on American culture and music, states that music has the 
Like any social discourse music is meaningful precisely insofar as at least some people believe that it is and act in accordance with that belief. Meaning is not inherent in music, but neither is it in language: both are activities that are kept afloat only because communities of people invest in them, agree collectively that their signs serve as valid currency. Music is always dependent on the conferring of social meaning ... the study of signification in music cannot be undertaken in isolation from the human context that create, transmit, and respond to it. (21)

In this sense, music dilates and spreads and it can also become a socially-constructed discourse and an unquestionable source of power. Some scholars, in fact, describe music as a "political issue" (O’Brien 15) that "changes the world in political terms" (Carson, Lewis and Shaw xii). From a feminist perspective, music serves as a public platform in which different models of gender organization are adopted, affirmed and/or contrasted. Through history - especially through Western history - music has led to intense controversy in terms of gender identity (Mcclary 8). Exploring popular music through critical and/or academic lenses is one valuable way to study the foundations of cultural configuration, more so in what concerns women. As a matter of fact, music tells about the social position that women have historically occupied.

In parallel to the development of the so called second-wave feminism, the emergence of a solid feminist criticism in the 1970s also contributed to the review and redefinition of critical approaches to popular music. In order to reveal popular music's patriarchal foundation, different feminist scholars in the second half of the $20^{\text {th }}$ century demanded, for instance, a redefinition of the otherwise almost all-male music canon that has marginalized women's production. In this way, feminist critical theory will examine the social and cultural conditions that contribute to the exclusion of women from visibility and recognition, vindicating their participation in music history and highlighting specific works by women artists. From the $1970 \mathrm{~s}$ onwards, more women have had access to critical inspection and, at the same time, more and more women have become visible in music charts (yet, much less than men) and some have begun to use the platform that music entails to explain and report feminist protests. It is the case of Riot Grrrl bands that bloomed in the 1990s and whose music and attitudes changed the way some people saw women's participation in genres such as punk rock. These bands set an example on how the union of feminism and music may open up debates. As I will show in the next pages, the why and how the Riot Grrrl emerged as one of the most important movements of the 1990s has a direct influence on the all-girl bands like Bikini Kill and, in fact, most of the concerns that the movement targeted also appear in their lyrics. Thus, in order to have a better understanding of the analysis of the lyrics I consider appropriate to anticipate some of the characteristics that the movement shares with third wave feminism and that also make it a unique blast in the development of future women musicians.

power to "act as an essential bearer of social, historical, and cultural knowledge" (5). In that same line, Simon Frith opens Taking Popular Music Seriously: Selected Essays by stating that "whether as an idea, an experience or an activity, music is the result of the play of social forces" (ix). 


\section{THE RIOT GRRRL MOVEMENT: A SISTERHOOD THAT OPENED UP SPACES FOR WOMEN}

After the underground culture succeeded in shifting the music scene in the late 1970s, a closer examination to women's participation in punk music (and more precisely to the roots of the Riot Grrrl movement) caught also the academic interest. Just to mention a few, recent works such as Cinderella's Big Score. Women of the Punk and Indie Underground by Maria Raha and The Lost Women of Rock Music. Female Musicians of the Punk Era written by Helen Reddington make a tribute to women who have shaped punk and the indie underground scenes in the United States and Britain. Other contributions like God Save the Queens: Pioneras del Punk by Cristina Garrigós, Nuria Triana and Paula Guerra make visible and reclaim the role of women in other scenarios as Spain and Portugal. And, more specific productions (e.g. Girls To The Front. The True Story of the Riot Grrrl Revolution or Riot Grrrl. Revolution Girl Style Now!) focus and recount the story of the Riot Grrrl, the movement from which Hanna's production arose and that becomes the background where discourse and text meet in form of lyrics.

Rooted in 1990 in Washington D.C., the Riot Grrrl movement was "characterized by the presence of women involved in the production and performance of music, sharing a strong feeling of sisterhood and bonding" (Alonso and Chaparro 84). This relatively "local" movement grew strong and got to influence American girls and altered the way feminism approached music. Indeed, thanks to the work of Riot Grrrl bands such as Bikini Kill and Le Tigre new ways of expression and activism appeared. Girls used art to express themselves and their ambition as artists strained an unquestionable push to exert their agency.

First, if we inspect the discourse surrounding the birth of the Riot Grrrl movement, it can be said that it was all about empowerment and vindication against sexism in punk and the dominant culture. During the 1980s gender differences and sexism within Washington D.C. all-male punk community became more and more obvious: "A prescriptive hardcore sound evolved in DC which emphasized instrumental virtuosity and speed which, unlike independent punk culture in Olympia, troubled the meanings and values of punk and DIY and produced more gendered experiences of the punk scene" (Downes 16). Thus, girls who enjoyed alternative punk music and attended punk concerts were commonly pushed to the sides as coat stands, got insulted, and asked to move out of the scene: "In a subculture that congratulated itself for presenting an alternative, in a realm that should have been a refuge, they found more of the same crap" (Marcus 92). The meaningful and symbolic space of the front lines was aggressively occupied and commanded by gender distinctions. The mistreatment that girls had to bear in concerts resembled the way in which girls were socially treated. Girls wanted to be active participants in the punk scene and in the 1990s the Riot Grrrl movement was going to pave the way for those girls who wanted to claim a spot on stage:

Tired, also, of encountering situations where their participation was limited by male contemporaries jostling for attention and undermining female expression by 
casting women in the role of follower and followed, the ideal of female collaboration and a stated desire to function as a community of women united against male oppression in all areas attracted hundreds of girls on the punk scene who no longer tolerated this shortchange. (Corrigan 150)

The Riot Grrrl started as a group of girls who met in Olympia during the weekends to discuss their lives, produce music, performances or art and think about possible political plans. The original first goal was to articulate a physical and discursive space to talk, share and learn about common and individual cultural and social concerns. But the significant part of the Riot Grrrl is that girls, who were usually targeted as consumers, became producers at last: "One of the biggest shake-ups riot grrrl initiated was the influx of girls becoming cultural produces for the first time" (Chidgey 114). Music was the most important and visible part of the movement but the Riot Grrrl production covered other cultural and artistic practices and expressions:

It was about music - being in bands, not watching them or being groupies- but it was also about finding a voice through writing, via fanzines; and it was about a political voice: anger about society's treatment of women, with domestic abuse, rape, sexuality, the need for safer streets, abortion rights and equal pay among the issues. (Barton)

As Laura Barton has stated, there were other ways of channeling feminist ideas that these women in the 1990s did not hesitate to use. From handmade tapes, EPs, LPs to CDs, zines, pamphlets and clothing, these girls approached feminism from a more active, collective, artistic and cultural way and set a model for future activist organizations. The girls talked about what meant to be female in a patriarchal culture and they discussed personal dreams. For them, these meetings were a kind of therapy against the depressions and anxieties they suffered during their adolescence. In many cases and for different reasons these girls had not been able to enjoy their childhood so getting involved with others who have suffered similarly made them feel comfortable and, for most of them the word girl turned into a term that adopted positive meanings such as sisterhood, collaboration and support. Girls were not famous and they were not icons, they were regular girls, between sixteen and eighteen years old, eager for a feminist revolution. Labeled antifamily for criticizing family roles or man haters for criticizing male behavior, these (feminist) girls were "ready to revolt over things like hallway gropes and sidewalk heckles, leering teachers, homophobic threats, rape, incest, domestic violence, sexual double standards, ubiquitous warnings against walking certain places or dressing certain ways [...]" (Marcus 92). Highly influenced by precursor subcultures and social movements such as the Mods, Punks, Hippies or Yippies (who made use of artistic and youthoriented strategies), together with feminist movements and lesbian gay bisexual transgendered and queer (LGBTQ) that used a strong DIY (Do It Yourself) mantra in an attempt to resist their negative representations in popular culture, Riot Grrrl tried to oppose the conflicting experiences of every day girlhood by creating a radical feminist movement of young girls (Downes 14). Riot Grrrl feminism turned into 
an alternative to the political or mainstream feminism as riot grrrls were re-writing feminism for a new century by widening limits, moving away from traditional marches and motivating girls to create art, zines, all-girl communities and bands that would help them express themselves.

Allison Wolfe (a member of the Riot Grrrl band Bratmobile), Molly Neuman (also in Bratmobile) and Jen Smith, decided to write a mini zine in order to have something that they could pass on in their shows. The terms 'girl riot' and 'angry grrrl scene' emerged as Molly and Allison were trying to devise an appealing name for the new zine and the result of blending both terms gave room to the Riot Grrrl term (Downes 25). The Riot Grrrl zine denounced "the general lack of girl power in society as a whole, and in the punk rock underground specifically" (Marcus 82) and gave voice to the collectivity between these girls and placed them within a community:

That there has never been an official periodical for the riot grrrl network is itself significant. In accordance with the riot grrrl ethos of decentralized organisation (creating a community without leaders or media stars), the importance of the network has always been for each girl to define what riot grrrl means to her, from her own place in the world (Chidgey 132)

Girls connected and supported each other and they started to put their frustrations and feelings into words, creating thus a zine culture that became a fundamental safe space for women to discuss and resist the cultural depreciation of women (Downes 18). Safety was a key concept for young girls as these zines became a channel where a community of young girls could exchange their personal experiences in a safe environment, allowing them to develop friendships and connections to other girls. As lyrics would do, these writings included varied topics such as body image, abortion, sexuality, self-harm or eating disorders (Chidgey 118) and thanks to the internet, home computers and cheap photocopies, these girls could write and distribute their own zines with little experience or skills and became producers for the first time. In 1993, zines proliferated, nearly 400 zines were being published in North America: "Grrrl zines were the coffee table reading and the fodder for dinner conversation" (Marcus 304). Zines like Riot Grrrl, Jigsaw, Girl Germs, Bikini Kill, Channel Seven, A Call to Arms, Leeds and Bradford Riot Grrrl! or In Spite of the Nigh were crucial in the development of Riot Grrrl. With a strong sense of aesthetic the Riot Grrrl marked the 1990 decade and found in lyrics its most personal outlet.

Music became the most visible and obvious cultural representation of this feminist movement. Riot Grrrl bands had a particular sound and they used music as a tool to resist society's definitions of them. Both that particular style and the ideological charge became recognizable signs:

Women and girls found their own voices and power in music, art, literary and political discourses, Riot grrrls began to rewrite and figure out themselves what it means to be a girl, a feminist, an activist, a musician or an artist. It opened up the possibility to share our experiences, tell our own stories and create our own language. A riot grrrl history is an insight into a provocative moment in modern day feminism, youth resistance and popular culture. (Downes 12) 
They use the lyrics as a way to express themselves and share personal (and political) experiences. Some women identified themselves with those narratives, what led to the creation of a strong bond between the singer and the (female) audience and a solid sense of community and belonging. Riot Grrrl bands mixed feminist theory and personal narratives, and wrote about women's issues and vindications, from a feminist perspective:

Though detractors claimed our music suffered, being "too political," I considered the points of contact between feminist art theory, grassroots activism, and punk rock as the success of our art. And we discovered that girls across the country were as hungry as we were to reimagine feminism for themselves, and to change the landscape of a masculinist punk scene that left them sitting on the sidelines. (Hanna, Gen X 132)

Riot Grrrl mixed feminist art and punk music and was the stimulant that many girls needed to voice their stories and it also became a new, inclusive and safe place where girls could perform their artistic ambitions whether in form of visual zines or punk songs. Tobi Vail, drummer in Bikini Kill, explained in a recent interview for The Guardian that to be in a band allows women's voices to be heard: "There's a power in seizing history. To me, that's what being a band allows you to access. If we see historicisation as an institutional force, let's be inclusive: let women's voices in" (Ewens). They were women writing to women and talking about women, for the first time in punk music. Lyrics included issues such as sexual harassment, artistic ambition, rape, or sisterhood and punk became a radical feminist platform for women who wanted to take part in the underground culture. Actually, Bikini Kill's publications (lyric sheets and zines) were openly feminist from the very beginning and worried about the audience not getting the right message they would share the lyrics in every show because for them it was really important that people could understand "what the lyrics were and that they were about radical feminism" (Hanna, Herstory repeats). Their songs became feminist anthems and their live shows were fascinating. They were described as "sexist against boys" (Marcus 111), for inviting the girls to the front rows of the concerts under the famous slogan "girls to the front" that Hanna screamed in an attempt to give girls a better view of the scenario and also to create a comfortable zone between her and the men on the pit (Marcus 255). Other negative references were "militant feminists" (Marcus 53) or "man-haters" (Marcus 22), probably because they used to sing about abuse and rape. Those appellations were not only dedicated to Bikini Kill, but also to other Riot Grrrl bands whose pro-girl messages were not understood by some male audiences. Their reply was full of anger and disdain, surfacing verbally with those epithets that I listed before and condemning Riot Grrrl bands.

It was hard being in a feminist band in the early 90's, I'm not gonna lie. People could be really mean and unforgiving towards us [...] I mean it's hard enough to be a girl in a band doing sound-checks in all-male settings, but having the "bitch" label proceed me to nearly every club got really tiring. It was draining trying to be nice all the time to prove people's preconceptions wrong. And half 
the time I was being called a bitch just cuz I asked the promoter for some water! It was also super schizo to play shows where guys threw stuff at us, called us cunts and yelled "take it off" during our set, and then the next night perform for throngs of amazing girls singing along to every lyric and cheering after every song. (Hanna, My Herstory)

Being aware or not, these girls were creating an alternative system based on feminist and political connotations: "Riot grrrl was by far one of the most undeniable effective feminist movements, turning academia into an accessible down-toearth language, making feminism a trend for the first time in history" (Ditto 8). In fact, due to the politics that the Riot Grrrl movement and the third-wave feminism share, some critics merge them and set the Riot Grrrl movement as an extension of the wave or as an artistic manifestation of it: "one of the most visible branches of what was dubbed third wave feminism" (McDonnell and Vincentelli). Both movements stand up against abuse, violence, body image and beauty constraints, racism, or sexism and all these political issues are present in authors of the third wave and writings of the Riot Grrrl movement. Besides, the two movements advocate for postmodern ideas of identity, and more personal and inclusive narratives are valid accounts of expression. When asked about the Riot Grrrl movement, the band Le Tigre explains that, together with other activist protests, it was part of a feminist history (third wave) from which it cannot be separated:

Many individuals, bands, zines, artists and scenes were lumped under this term [Riot Grrrl] once the «sexy new» punk feminism gained a little media attention. This gave the false impression that there was a centralized ideology or leadership unifying disparate constellations of feminist art and agitation. Journalistic narratives of Riot Grrrl also tended to isolate it from both a larger feminist history and from its own cultural moment in which a variety of media-savvy activist groups were changing the face of social protest (for example, ACT-UP!, Queer Nation, the Guerilla Girls, and WAC). (Letigreworld)

According to Kathleen Hanna, the 1990s movement is a music scene that raised consciousness in forms of feminist zines and songs, but "it didn't formulate policy, or even protest too much outside the parameters of underground music" (Hanna, Gen X 134). Hence, Riot Grrrl contributed to the revival of feminism and could be described as a radical musical movement shaped by politics that encouraged girls and women to make use of their artistic inspiration. Obviously, all these pro-women rights demonstrations called the media attention, which was so enormous that shocked most Riot Grrrl bands. At the beginning, the media cover was important for the riot grrrls as their new bands reached a wider audience across America, but they also turned to stereotypes and, instead of judging the movement as an important happening that was shaping underground music and feminism, they attempted to discredit bands' ideas and actions; so some Riot Grrrl bands decided to call a media blackout, something that caused fragmentation between the girls. As many other subcultures, "Riot grrrl experienced its own 'false feminist death syndrome' as the media declared riot grrrl a political failure, a genre of bad music 
and a simplistic reinvention of (male) punk" (Downes 41). In effect, the Riot Grrrl culture expanded very fast and bands such as Bikini Kill, Bratmobile or Heavens to Betsy are good examples of almost all-girl punk rock bands who managed to challenge the male dominated punk underground of the 1990s. Encouraging girls to form music bands and asking them to come to the front rows of punk concerts, Riot Grrrl bands were turning the male-dominated punk scene into a community where music was free and available to everyone, regardless of their sex and in a way it can be said that "...riot grrrl reinvented punk" (Ditto 8).

Thanks to Riot Grrrl bands, young girls who listened to punk rock music could find encouragement and direction from openly feminist bands, finding a source for confidence and determination. I would even dare affirm that this precise musical and cultural movement, with female bands and female protagonists, was one important step on the contemporary endeavor to vindicate and celebrate the role of female musicians. And echoing Hanna's slogan, girls finally found a space and "got to the front." With the Riot Grrrl movement, more and more women had the chance to become visible not only over the stage, but also afterwards, when the canon is arranged and history gets written down. Thanks to the freedom that women felt when writing lyrics (and the ideological freedom that punk music entailed), most took the opportunity to use these literary productions as an expression of their feminist ideas and their discourses contributed to the theoretical and intellectual body of the third wave of feminism.

\section{SISTERHOOD AND SPACE IN KATHLEEN HANNA'S LYRICS}

The Riot Grrrl movement became an ideal arena to discuss feminist topics, generate music and demand equality and Bikini Kill and Le Tigre (where Kathleen Hanna had the role of lead singer) are two great examples where to find feminist discourses that go in hand with empowering vindications. Bikini Kill started playing in 1990 and included the names of Tobi Vail, Billy Karren and Kathi Wilcox. The band became one of the most influential and characteristic of the Riot Grrrl movement. Hanna's music projection did not stop there though and her music career has expanded in Le Tigre (1998-), where Hanna has worked with Johanna Fateman, Sadie Benning and JD Samson. Her work in both bands is remarkable, yet, thanks to her role in Bikini Kill she became an influential activist in the third wave of feminism and (main) leader of the Riot Grrrl.

Bikini Kill would combine politics and punk music in order to oppose the male-dominated underground culture at the time. These discourses became really important to raise awareness about diverse aspects that affected women's identities. Hanna's lyrics are characterized by a powerful diction and a straightforward imagery. Most of the lyrics she wrote for Bikini Kill (1990-1998) and later Le Tigre (1998-2006) are openly feminist as she included topics such as patriarchy, alienation, politics, sexual abuse and claims on spatial empowerment and all-girl communities. Also, as third wave feminists, riot grrrls focused on establishing feminist spaces where women could meet and share their experiences in a safe environment. 
These girls asked for places in which they could materialize a sense of actual sisterhood, providing resources for communal and interpersonal activities, artistic creativity and determined self-expression. Indeed, these topics are expressed in several songs in Bikini Kill and Le Tigre, where Hanna makes straightforward references, for instance, to the creation of a bigger and cohesive community of girls, and to spaces like the streets (both as a place that did not grant safety for women and as an expanse for revolutionary feminist meetings) and concert venues where girls could finally claim a spot on stage or on the front of the audience.

It is well documented that the girls involved in the Riot Grrrl movement were connected to each other in a supportive way that had not been seen before. A real feeling of sisterhood was felt within the movement and all the girls who were part of it and played different roles -e.g., as performers, Zine writers or counselors- supported each other unconditionally. The bands Bikini Kill and Le Tigre refer to this alliance between women, which was also of immense relevance for the feminist movement. This bond and community were the result of girls meeting in spaces where they could get together and exchange personal experiences, impressions and feel safe. In fact, this is also one of the most significant characteristics of the Riot Grrrl movement. The girls who wanted to participate in bands or attend punk concerts requested a space where they could express artistically and where they could feel valued and respected and not put to the side of the concert rooms. In order to achieve that goal, riot grrrls needed a safe space. This topic is expressed in several songs both in Bikini Kill and Le Tigre, and they make references especially to physical spaces such as the street (both as a no longer safe place for women and as a point of revolutionary feminist meeting) and more specific locations as concert rooms. In the next pages, and by applying the FCDA approach to her lyrics, I provide some examples related to space, sisterhood and feminist vindications that were discussed in the previous paragraph.

In this study I am analyzing the lyrics and I am not making a musicological approach to the songs, so notions of rhythm, musicality or instrumentation are not discussed. I focus on a specific corpus of texts that include Kathleen Hanna's lyrics in Yeah Yeah Yeah Yeah (1993) and Reject All American, (1996) for Bikini Kill and Le Tigre (1999), Feminist Sweepstakes (2001), and This Island (2004) for the band Le Tigre. This election is based on the content and their feminist thematic pertinence for the work and not all the songs included in each album are analyzed. I want to see how feminist concepts are enunciated in the lyrics and the implications that a reformulating and rethinking of them may have in feminism and society. In this sense the lyrics that I have chosen have a greater significance for my study and are more pertaining to focus on (in terms of feminist topics or relevance) whereas others do not specifically match the purpose of the analysis. The seven songs "Rebel Girl," "Hot Topic," "On The Verge," "False Start," "After Dark," "LT Tour Theme" and "FYR" focus on feminist spaces and sisterhood or girl communities so they reaffirm their value for my study. Moreover, as an important part in the FCDA I pay especial attention to lyrics' communicative interaction (e.g. audience and focalization), their linguistic and narrative style, syntax and I also examine figurative languages such as symbolism, imagery, metaphors or irony. 
In 1993 Bikini Kill released what became its most recognized anthem about sisterhood: "Rebel Girl," which is in the $27^{\text {th }}$ position of the Rolling Stone list "Most Excellent Songs Of Every Year Since 1967" (Most) and, as Sara Marcus suggests, it "was well on its way to becoming a movement's fight song" (110). Produced by Joan Jett and written by Hanna, who was inspired by artist Juliana Luecking, the famous song "Rebel Girl" is considered a calling to solidarity between feminists. The song portrays a girl from the hood who is a potential role model for American girls. The revolutionary manners and style that Hanna uses to attract girls to her political side encourage girls to follow this new 'queen', whose speeches and hips movements evoke an authentic revolution. The use of the third person in the song opens the possibilities for interpretation. It amplifies the literary implications of the unconstrained characterization, providing the opportunity to strengthen this 'rebel girl' within Hanna's own cultural and social symbolic and representative command, as she became the inspiration and idol of some American adolescents, making of their isolated world a real sisterhood.

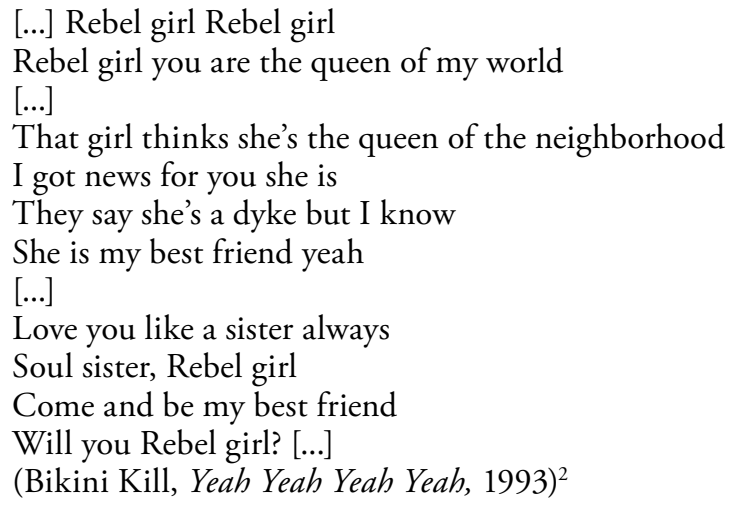

In relation to that strong and factual sisterhood, it is not new the criticism that some make about the lack of role of mentors or antecedents that help create that community. It is true that women may find fewer role models as a result of women's historical absence from some artistic domains like music. Yet, in the song "Hot Topic," Hanna mentions several inspirational and powerful figures in art. As the band itself admits on their blog, it was Hanna's dream to write a song like this to celebrate the people go give the band the strength as artists and feminists (leti-

${ }^{2}$ Lyrics belonging to Bikini Kill and Le Tigre sound recordings do not include a page citation - as some are taken either from their official websites (letigreworld.com) or from an internet website related to punk music lyrics (plyrics.com). I am using the following references (Band, sound recording, year) to distinguish between Bikini Kill and Le Tigre and to make available the sources of each song and to make clear the chronological span. Also, just the more relevant extracts of each song are included in this work and their arrangement is the same as in the original lyrics. That is why they do not adjust to the style guidelines. 
greworld). Hanna is mainly asking these women (and all the people involved in the search for equality) to continue working, as their legacy would be uplifting for future girls. Within 3 minutes and 44 seconds Hanna lists famous and (some) not so popular women and a few men, in an attempt to raise awareness of their works and at the same time they are making them visible. Many of the names below belong to the musical world, as it is the case of the Butchies, Gretchen Phillips, Japanese and New York based band Cibo Matto, Hanna's friends from Sleater-Keaney or American bluegrass singer and bassits Hazel Dickens, Nina Simone or Joan Jett. Others, on the other hand, are mainly known for their contributions in the literary realm: Mab Segrest, Dorothy Allison, Gertrude Stein or Gayatri Spivak. Italian painter Carol Rama, American auto racer Shirley Muldowney or tennis player Billie Jean King are mentioned too. Performers, visual artists, activists... the list is long yet it is interesting to note the presence of three men: American novelist and civil right activist James Baldwin, AIDS activist, photographer, painter and artist David Wojnarowicz and American (transgender) jazz musician Billy Tipton. It is worth mentioning that all these men are linked to causes that many feminist groups also support, and it is probably on purpose that Hanna mentions them, to set examples and show that anyone regardless of their sex or cause can be influential for future generations.

[...] Carol Rama and Eleanor Antin/Yoko Ono and Carolee Schneemann/You're getting old, that's what they'll say, but/Don't give a damn I'm listening anyway/ Stop, don't you stop/ I can't live if you stop/Don't you stop/[...]/Urvashi vaid, Valie Export, Cathy Opie, James Baldwin/Diane Dimassa, Aretha Franklin, Joan Jett, Mia X, Krystal Wakem/Kara Walker, Justin Bond, Bridget Irish, Juliana Lueking/ Cecelia Dougherty, Ariel Schrag, The Need, Vaginal Creme Davis/Alice Gerard, Billy Tipton, Julie Doucet, Yayoi Kusama, Eileen Myles/ Oh no, no, no don't stop (Le Tigre, Le Tigre, 1999)

Suzy Corrigan defines the song as "in many ways a blueprint of aesthetic influence on punk rock feminism" (145) and in fact, "Hot Topic" is a clear example of how important it is to have role models to follow, especially for teenage girls, and to make it easier for future generations so they do not have to start from scratch. In the past, some young girls who wanted to participate in a rock scene that blocked and limited their agencies decided to give up because the references they got of successful women were just exceptional. The balance showed that the negative things surpassed the positive. Nevertheless, as this song tries to exemplify, the list of uplifting women is extended, and will continue to be so as long as their stories are accounted and told. Without any doubt, riot grrrls looked back to some leading roles that were inspiring but at the same time riot grrrls were themselves setting a community of precedents for generations to come.

Close to those lines and following with the sense of community and sisterhood typical of the Riot Grrrl, the song "On the Verge" depicts a friend (perhaps a Riot Grrrl friend) depressed lying on bed and Hanna showing, with a truthful gesture, support and solidarity towards her. Hanna claims that girls are going to meet on the 'outside', on the streets, to start an ignition and protest. They are now turning tables, and 'on the verge' of changing things. The song asks girls to leave 
sadness or fears behind and encourages them to grab bags filled with wipes, mic or video cameras, to join the riot grrrls and start all together a revolution based on artistic expression that will free them from patriarchal attitudes and confinement.

So get your bags packed now and I'll meet you on the outside

"X"-out all self-supervision, get your keys out, now start the ignition

We're on the verge of

$[\ldots]$

When you're shipwrecked on your mattress

I'll come in and show you how

To hijack the past and wind up in the right now

Grab some clothes, three chords, and a video camera

Maybe a mic, some hand-wipes, a typewriter, and a hammer

"X"-out all self-supervision, get your keys out, now start the ignition

(Le Tigre, This Island, 2004)

Along that appeal for a sisterhood and change, in "False Start" Hanna openly and sincerely asks for a wider commitment and bond between the girls so as to grow stronger and meet in the outside to start their revolt. The singer expresses a desire to go "outside" with a more motivational attitude and a more vindictive approach. Here the "outside" as a free space is opposed to the room, which is filled with failure feelings and where women have been "stuck" and unable to react and act. Now these girls are motivated, they are in the proper mood to start what they defined both as a "casual" and "obligation" factor, probably referring to the feminist movement, which for some was just another continuation of the waves whereas for others was a mandatory motion to end oppression and inequality. Hanna goes on and states that no more plans will be developed and indeed everything will be suspended as the only project that matter is the one where girls are vindicating their rights.

[...] Wanna go outside

Don't you wanna go outside

Been stuck inside your room so stranded-like and full of doom

all year

Time out for good behavior adds up to what you want it to

[...]

That informs a motivation-

casual or obligation-fictitious circumstance

suspending all your future plans

wait for you outside.

$[\ldots]$

We're meeting at this place I wanna see you,

see your face again [...]

(Bikini Kill, Reject All American, 1996)

The claims analyzed in these four songs are bound to one of the main vindications of the different waves of feminism: women's need for a solid community and 
a unique sisterhood based on spatial command in any aspect of their lives. Also, as I have tried to argue, these songs make reference to the street as places where women claim agency in male-ruled territories and where power structures and inequalities are still represented. Yet, by honest and forthright feminist vindications, Hanna claims space (the street) as a domain where women should also be free, safe and accounted. The choice of "outside" is relevant as long as the public space is a field hardly known and investigated by women, who are supposed to be condemned to occupy the private sphere. Emphasizing this, Hanna is challenging the patriarchal conventions and limitations and encouraging women to take the next step and join the girls' revolution publicly and freely from any kind of restriction.

And apart from the streets, other locations, however specific like concert venues or more general such as rooms, were also targets for women's spatial manifestation of their search for recognition and agency in punk. Venue rooms were sometimes places where passive roles for women were performed, such as the "coat stands" figure that I have used before. In these spaces, women also felt alienated from a scene that they wanted to enjoy. In this sense, it is significant how Hanna, in her latter project Le Tigre, explores and discusses the meaning and transcendence of the famous expression that held the spirit of the Riot Grrrl movement. The slogan "girls to the front" brings forward echoes of that spatial demand that I have argued in the previous examples. By its use, girls reclaimed a space that was also theirs and challenged and in a way upset the boys who did not accept their presence in the music scene as equals. Girls move forward and started to occupy the front of the concert rooms and one of the most important artistic movements of the 1990s.

An example of this is the song "After dark." Firstly, it provides the audience with illustrative examples of patriarchal expectations. The song uses symbols such as a 'brush' to structure a dialogue on patriarchal assumptions. A brush can be read as an element associated with beauty standards that reinforce stereotypes for women and men. Hanna addresses women, calls their attention and compels them to relinquish the brush (and thus reject standards of beauty) for the microphone. Spatial location is once again used in the song as the language that describes how that performance of freedom will take place: the front row of a concert becomes again a territorial metaphor of dispute and autonomy.

[...] I will be in the front row later when your brush becomes a mic Maybe we could change this game forever [...]

(Le Tigre, This Island, 2004)

The chant evokes again sisterhood, solidarity and sorority between girls. Hanna seems to talk from experience, with a certain tone and attitude, being harsh and sincere in the lyrics, blending message and emotion and addressing a girl that may be new in the music industry. In the following verses she says that in case someone wants to put an end to a girl's dreams and artistic qualities she can contact her, no matter the time of the day, no matter if it is "after dark." As Hanna says, some may argue that it is not the right time for women to try and they will always cast doubts on them. Hanna affirms that she will be with her friend at all times and together will 
fight all the limitations that block their artistic development. She resolutely states that they are going to cross the line that interferes with the success they deserve.

[...] They might say we're both crazy

I'm just glad I found you, baby

I don't want someone telling me no-oh-oh "you're out of time"

I don't mind being debated as long as you're with me tonight

I'm not gonna give up easy, we were made to cross the line [...]

(Le Tigre, This Island, 2004)

The sense of sisterhood and protection is really present in this song too, and emulates the unconditional support that the girls belonging to the Riot Grrrl shared. The community of girls that was born from the movement fought for a place in music that should not be affected by gender or sex. All the girls bore the same famous mantra in mind: the "girls to the front" to which I referred before and that they shouted in concerts.

This allusion to the Riot Grrrl slogan is appropriately illustrated in "LT Tour Theme," for example, which clearly makes reference to those boys that occupy all the front part of the room and then start to mosh, discouraging girls to participate. Fortunately, all that changed after some bands emerging from the Riot Grrrl movement started to ask girls to go to the front so they could enjoy the performances as well. In the song, Hanna states that the presence of those girls moving forward and reaching close to the stage ignited recognition and celebration on the bands up in the stage: that was what they were trying to vindicate, that the situation of women within the spatial order of a concert was reverted.

Yeah, its weird when the club is really crowded

And there's no way that we can do every song thats shouted

But we'll still try to push you towards abandon

Yeah, every night is something we can't plan on

[...]

Yeah you know the guys with the digi cameras

Push to the front and then they just stand there?

But then we see the girls walking towards the dance floor

And we remember why we go on tour [...]

(Le Tigre, Feminist Sweepstakes, 2001)

Included in the same LP, the song "FYR" makes a similar reference to the same Riot Grrrl slogan but, at the same time, it also criticizes that after all the fight in which women were involved in this musical fulfilment of certain ideals and motifs encompassed in the third-wave feminism, some things remain unchanged. The title "FYR" (Fifty Years of Ridicule) hints that after all the activism and struggling, some women consider that the outcomes amount to a ridiculous defeat. In the lyrics Hanna voices how these women still wonder if one day they will feel free, happy and safe. The topics of safety and freedom are very well illustrated in this song. Taking as a backbone the specific story of a woman who travels alone in the 
New York subway without anyone bothering or harassing her, Hanna articulates a musical discourse in which it is possible to compare this unusual event with a normal situation in which women are harassed and deprived of their freedom. This, as I have mentioned before, becomes one of the key elements in the feminist ideology that these women were trying to elaborate through music.

\author{
[...] Feminists we're calling you \\ Please report to the front desk \\ Let's name this phenomenon \\ It's too dumb to bring us down \\ [...] \\ I wonder whether we could be happy in a place like that \\ $[\ldots]$ \\ I had a friend who did that \\ She used to ride the subway in New York City \\ From the beginning of the line at New Lots Avenue \\ All the way up to 241st Street in the Bronx \\ And nobody would bother her \\ (Le Tigre, Feminist Sweepstakes, 2001)
}

It must be mentioned that Bikini Kill belongs to a certain period and a certain movement- that of the Riot Grrrl- in which revolution and reaction were part of the power and spirit of the songs and the whole band, whereas Le Tigre started playing in the $21^{\text {st }}$ century, a time when the Riot Grrrl was gone and Hanna had pursued a long musical story. Thus, there are points in common between the content of the songs, but there is also a change in Hanna's attitude in Le Tigre, as if she did not need to justify her statements and she was already aware of her own career. In this sense, we can understand the somehow pessimistic tone of the title, which unveils a feeling of defeat considering that some significant issues (such as abuse against women) still pended at that time. In spite of this, the words in the song transmit strength and encourage girls to keep up with a fight that sadly was (and it is) not over.

To sum up, with an informal direct linguistic and narrative style, Hanna's work in the lyrics for Bikini Kill and Le Tigre changed and challenged the sometimes fixed definitions of punk and the gendered roles in the underground music. Her work means a reevaluation of musical texts where lack of punctuation or any formal patterns and the use of repetitions work as a formal device. The singer employs cut-edged lines and direct (and aggressive) expressions, what make the lyrics really emphatic. Due to the new creative chances that the Riot Grrrl offered, lyrics became a land of opportunity for girls like Hanna that redefined what is to be a woman in a band.

The Riot Grrrl movement was the output of a solid and strong community that punk girls forged during the 1990s in an attempt to defy the sexist direction that punk music was acquiring. Being alienated and feeling disfranchised artists like Kathleen Hanna, Allison Wolfe or Molly Neuman looked for a space where they could exchange ideas and creatively express themselves. Indeed, if one thing 
is representative of the movement is the respectable and admirable atmosphere that filled any kind of artistic expression (e.g. zines, clothing, music) in which girls were involved. Team spirit, respect and help were the grounds of a movement that came up from bedrooms, classrooms and bars over North America and Europe (Monem 7). Until that moment, few movements or scenes achieved the strength and commitment which the Riot Grrrl could show off from. As the "Rebel Girl" song claims, the riot grrrls became "the queen" of many girls" worlds in America and overseas and drastically changed the way women's presence was considered in some genres such as punk.

That feeling of bonding and sisterhood that these girls created was in need of a space where to freely and safely express their feminine conditions. In the lyrics of Bikini Kill and Le Tigre we come across examples in which Hanna openly asks for feminist spaces within the underground sphere in which her bands were positioned. These references to street and concert rooms are sometimes used just as a mere functional description of context. At the same time, these territorial examinations are significant because they reflect the vindications and struggles of women involved in feminism. The conquering of these spaces meant also a more important achievement: a step towards equality in music. In a sense, the metaphor that this territorial overcoming implies echoes some discourses that feminists have confronted and assessed. Indeed, the Riot Grrrl movement became a feminist space where any girl could participate and the lyrics that some of these girls wrote down can be now read as artistic representations of territories that women reclaimed to conduct their achievements.

Taking into account the socially constructed implications based on gender that affect the production and also consumption of punk music and women's participation in it, girls were in need for a space where they could express themselves freely and where the sisterhood that they were creating could find a solid foundation. Thus, music, apart from reproducing power structures, becomes a powerful means not only to revise and rewrite universal 'truths' but also to socialize and respond to social challenges. Besides, music emerges as a positive source of influence for women, a tradition that serves as a basis for the future. One of the main objectives of some feminists involved in music is to unveil women's undeniable contribution to punk culture and to reevaluate their works in the context in which they were written. In this context I find appropriate to present FCDA as it is an approach that may bring original and new debates to the study of lyrics. Lyrics, as literary products that convey meaning, are discourses produced by and in society. My intention with this analysis was to prove that there are ways to re-appropriate discourse and transform its powerful characteristics in favor of equality. Hanna uses the lyrics to address safe spaces and sisterhood, matters that directly affect women's condition and, by doing so, the artist is reformulating the way lyrics intertwine with feminist discourses and politics. The FCDA evidences that lyrics are a solid tool that invites to reject patriarchal attitudes or stereotyped standards, informs of inspirational figures for women artists and, finally, asks for women's involvement and sorority. Music thus becomes a cultural platform that helps in women's fight. In the case of punk, women (and more precisely those involved in the Riot Grrrl movement like Hanna), have 
clearly brought a different, subversive but clarifying light to the history of music. Their stories should not fall into oblivion and lyrics may serve as a platform where to expose women's stories, their potential agency and undoubtedly influence and, in sum, be of strong relevance so girls do not have to reinvent the wheel once again. In conclusion, the story of the Riot Grrrl movement is the story of those who refused to follow some standards, set a template, broke taboos, created their own rules, and broke new ground. Theirs is a story worth telling.

Enviado: 31 de mayo de 2020; ACEPTAdo: 28 de septiembre de 2020 


\section{REFERENCES}

Alonso Alconada, Soraya and Chaparro Sainz, Ángel. "Punk Pioneers: Chicana Alice Bag as a Case in Point." Lectora, 23 (2017), pp. 83-98.

Attali, Jacques. Noise: The Political Economy of Music. Minessota: University of Minnesota Press, 1985.

Barton, Laura. "Grrrl power." The Guardian, March, 2009 (https://www.theguardian.com/lifeandstyle/2009/mar/04/grrrl-power-music).

Bikini Kill. Yeah Yeah Yeah Yeah. Kill Rock Stars, 1993. CD.

Bikini Kill. Reject All American. Kill Rock Stars, 1996. CD.

Carson, Mina, Lewis Tisa and Shaw, Susan M. Girls Rock! Fifty Years of Women Making Music. Kentucky: University Press of Kentucky, 2004.

Chidgey, Red. "Riot Grrrl Writing," in Monem, Nadine (ed.), Riot Grrrl. Revolution Girl Style Now!, London: Black Dog Publishing, 2007, pp. 100-145.

Corrigan, Suzy. "Art, Politics and How One Grrrl Joined the Feminist Timeline," in Monem, Nadine (ed.), Riot Grrrl. Revolution Girl Style Now!, London: Black Dog Publishing, 2007, pp. $145-168$.

Ditto, Beth. "Foreword," in Monem, Nadine (ed.), Riot Grrl. Revolution Girl Style Now!, London: Black Dog Publishing, 2007, pp. 8-9.

Downes, Julia. "Riot Grrrl: The Legacy and Contemporary Landscape of DIY Feminist Cultural Activism," in Monem, Nadine (ed.), Riot Grrrl. Revolution Girl Style Now!, London: Black Dog Publishing, 2007, pp. 12-52.

Ewens, Hannah. "Riot Grrrl Pioneers Bikini Kill: 'We're Back. It's Intense'. The Guardian, June, 2019 (https://www.theguardian.com/music/2019/jun/09/bikini-kill-riot-grrrl-were-backits-intense).

Frith, Simon. Taking Popular Music Seriously: Selected Essays. Farnham: Ashgate Pub Co., 2007.

Garrigos, Cristina, Triana, Nuria and Guerra, Paula. God Save the Queens: Pioneras del Punk. Barcelona: 66rpm ediciones, 2019.

Hamilton, Heidi E. and Schiffrin, Deborah (eds.). The Handbook of Discourse Analysis, West Sussex: Wiley Blackwell, 2015, pp. 466-485.

Hanna, Kathleen. "Gen X Survivor: From Riot Grrrl Rock Star to Feminist Artist," in Morgan, Robin (ed.), Sisterhood Is Forever. The Women's Anthology for a New Millenium. New York: Washington Square Press, 2003, pp. 131-137.

Hanna, Kathleen. "Herstory Repeats." Old Dominion University Norfolk, VA: Guest Lecture, 2011 (https://www.youtube.com/watch?v=NcmIjU2dR-E).

Hanna, Kathleen. "My Herstory.” (http://www.letigreworld.com/sweepstakes/html_site/fact/khfacts. html).

Hiroshi Garrett, Charles. Struggling to Define a Nation: American Music and the Twentieth Century. Berkeley: UC Press, 2008.

Holmes, Janet and Meyerhoff, Miriam. The Handbook of Language and Gender. Oxford: Blackwell Publishing, 2003. 
Kendall, Shari and Tannen, Deborah. "Discourse and Gender," in Tannen, Deborah, Hamilton, Heidi E. and Schiffrin, Deborah (eds.), The Handbook of Discourse Analysis, West Sussex: Wiley Blackwell, 2015, pp. 639-660.

Kotarba, Joseph A. and Vannini, Phillip. Understanding Society Through Popular Music. New York/ Oxon: Routledge, 2008.

Lazar, Michelle M. "Feminist Critical Discourse Analysis: Articulating a Feminist Discourse Praxis." Critical Discourse Studies, 4: 2 (2007), pp. 141-164.

Le Tigre. Le Tigre. Mr. Lady Records, 1999. CD.

Le Tigre. Feminist Sweepstakes. Mr. Lady Records, 2001. CD.

Le Tigre. This Island. Universal Records, 2004. CD.

LETIGREWORLD. (http://www.letigreworld.com/sweepstakes/flash_site/fact/fact.html).

Litosseliti, Lia and Sunderland, Jane. Gender Identity and Discourse Analysis. Discourse Approaches to Politics, Society and Culture. Philadelphia: John Benjamins Publishing Company, 2002.

Marcus, Sara. Girls to the Front: The True Story of the Riot Grrrl Revolution. New York: Harper Perennial, 2010.

McClary, Susan. Feminine Endings. Minneapolis: University of Minnesota Press, 1991.

McDonnell, Evelyn and Vincentelli, Elisabeth. "Riot Grrrl United Feminism and Punk. Here's an Essential Listening Guide.” Nytimes, May, 2019 (https://www.nytimes.com/interactive/2019/05/03/arts/music/riot-grrrl-playlist.html).

Monem, Nadine (ed). Riot Grrrl. Revolution Girl Style Now!. London: Black Dog Publishing, 2007.

Most eXCEllent SONGS OF EVERY YeAr SINCE 1967. (http://archive.li/mjtkj).

O’Brien, Lucy. She Bop.The Definitive History of Women in Popular Music. London: Jawbone Press, 2012.

Raha, Maria. Cinderella's Big Score. Women of the Punk and Indie Underground. Berkeley: Seal Press, 2005.

Reddington, Helen. The Lost Women of Rock Music. Female Musicians of the Punk Era. Sheffield: Equinox Publishing, 2012.

Van Dijk, T.A. "Critical Discourse Analysis," in Tannen, Deborah, Hamilton, Heidi E. and Schiffrin, Deborah (eds.), The Handbook of Discourse Analysis, West Sussex: Wiley Blackwell, 2015, pp. 466-485. 
